\title{
RESEARCH PAPER \\ New seed collections of North American pitseed goosefoot (Chenopodium berlandieri) and efforts to identify its diploid ancestors through whole-genome sequencing
}

\author{
Eric N. Jellen, David E. Jarvis, Spencer P. Hunt, Hayley H. Mangelsen, and \\ Peter J. Maughan \\ Brigham Young University, Plant \& Wildlife Sciences Department. 4105 LSB, Provo, Utah, 84602, USA.
}

\begin{abstract}
E.N. Jellen, D.E. Jarvis, S.P. Hunt, H.H. Mangelsen, and P.J. Maughan. 2019. New seed collections of North American pitseed goosefoot (Chenopodium berlandieri) and efforts to identify its diploid ancestors through whole-genome sequencing. Cien. Inv. Agr. 46(2): 187-196. Pitseed goosefoot (Chenopodium berlandieri) is an ecologically diverse wild/weedy North American species within the primary gene pool for improving South American quinoa (Chenopodium quinoa). Both taxa are 36-chromosome allotetraploids with subgenomes AA and BB. The A genome is found in a large number of diploids in the Americas, along with one Northeast Asian taxon, and was recently shown to be the maternal ancestor, while the paternal B genome is closely related to several extant Eurasian diploids. Two of our primary objectives were 1) to determine the extent of genetic diversity in the allotetraploid C. berlandieri-quinoahircinum complex and 2) to characterize the evolutionary path from polyploidization to domestication in these taxa. In an effort to survey genetic diversity, in 2018, we made seed collections of southern Texas, southern Great Plains, and New England coastal ecotypes of $C$. berlandieri as well as sympatric diploids. With respect to the second goal, we performed wholegenome sequencing of two Sonoran Desert Chenopodium A-genome diploids in subsection Cellulata and Andean cultivated C. pallidicaule in subsection Leiosperma. When paired reads were aligned to the whole-genome reference of $C$. quinoa strain 'QQ74', the match percentages were $99.31,99.23$, and 98.53 for $C$. watsonii, $C$. sonorense, and $C$. pallidicaule, respectively. These data strongly support $C$. watsonii as being the most closely related of these three species to the A-genome ancestor of quinoa. Ongoing sequencing efforts with a larger panel of diploids are aimed at identifying the maternal ancestor of C. quinoa and C. berlandieri, if extant.
\end{abstract}

Keywords: Chenopodium, DNA sequencing, genetic resources, quinoa.

\section{Introduction}

Quinoa (Chenopodium quinoa Willd., $2 n=4 x=$ 36) cultivation is spreading rapidly throughout the world in response to increasing consumer

Received Mar 06, 2019. Accepted Jun 04, 2019.

Corresponding author: rick_jellen@byu.edu demand for this highly nutritious South American pseudocereal. In addition to their nutritional benefits, most quinoa strains tend to be highly tolerant of salt- and drought-affected production environments. Quinoa's principal weakness is that it is highly susceptible to a wide range of pests and diseases and heat during its reproductive cycle. This susceptibility occurs because 
the crop evolved for thousands of years under domestication in highland Andean and Chilean coastal environments, which have mild daytime high temperatures and are relatively geographically isolated from Eurasian and North American pest and pathogen populations. One manifestation of quinoa's heat susceptibility is that it is spontaneously cross-pollinated by weedy pitseed goosefoot (C. berlandieri Moq.) where the two co-inhabit quinoa production fields in warm North American environments (Wilson and Manhart, 1993). A series of recent cytogenetic and DNA sequencing studies have confirmed that these two taxa have a close relationship, constituting a single biological species with a genome composition of AABB and with $C$. berlandieri at the root of the allotetraploid clade that includes domesticated quinoa (Jarvis et al. 2017; Kolano et al. 2016; Walsh et al. 2015; Brown et al. 2015; Storchova et al. 2015). This clade also includes forms that were anciently domesticated as seed and vegetable crops at various times in Mesoamerica (Wilson and Heiser, 1979) and eastern North America (Kistler and Shapiro, 2011; Smith and Yarnell, 2009; Gremillion, 1993; Smith, 1984). In addition, sequencing of cpDNA and mtDNA genomes recently confirmed that of subgenomes $\mathrm{A}$ and $\mathrm{B}$, the former is most likely the cytoplasmic donor and was, consequently, the maternal ancestor of the allotetraploid clade and that the Western Hemisphere was most likely where the hybridization event took place (Maughan et al., 2019).

These results point to two critical lines of research, one basic and the other applied. Fundamental research should focus on the identification, collection, and preservation of the $\mathrm{AA}$ and $\mathrm{BB}$ diploid species that are most closely related to the $C$. berlandieri-C. quinoa complex. Previously cited studies (Maughan et al., 2019; Jarvis et al., 2017; Kolano et al., 2016; Walsh et al., 2015; Brown et al., 2015; Storchova et al., 2015) indicated that both $C$. suecicum Murr. and C. ficifolium Sm. carry the BB genome, and these two species have recently been shown to be cross-fertile (Hodkova and Mandak, 2018); however, identification of the
A-genome ancestor may prove more difficult, with $C$. watsonii A. Nels. emerging as the leading candidate. Chenopodium watsonii, also known as Watson's stinking goosefoot, thrives on disturbed high-nitrogen soils in the upper Sonoran Desert and adjacent intermediate-elevation woodlands of Arizona, New Mexico, and Utah, although its range would certainly have moved during the 3.3-6.3 million years since the estimated polyploidization time (Jarvis et al., 2017). Wilson (1981) hypothesized that southwestern North America was the best candidate for the center of origin of the allotetraploid species complex, being the only region in the Americas where $C$. berlandieri zschackei is known to be sympatric with Cellulata diploids. However, this hypothesis certainly demands further testing, especially given that comprehensive taxonomic descriptions, including seed and plant specimen collections, of the North and South American A-genome diploids are ongoing, as exemplified by a very recent report refining an important group of southwestern North American taxa in the subsection Cellulata complex that includes $C$. watsonii (Benet-Pierce and Simpson, 2017).

From an applied research perspective, efforts to collect and characterize samples representative of the broad geographic and morphological range of C. berlandieri and its wild/weedy South American cousin, C. hircinum Schrad., are essential. Pitseed goosefoot is currently subdivided taxonomically into subspecies nuttaliae and berlandieri. The former includes cultivated and associated weedy forms from South-Central Mexico, while the latter includes the wild and weedy ecotypes berlandieri from interior southern Texas, boscianum from the Gulf of Mexico coast, bushianum from interior eastern North America, macrocalycium from the Atlantic Coast, and sinuatum from southwestern North America. While all of these botanical varieties of $C$. berlandieri ssp. berlandieri have somewhat restricted geographic distributions, the additional botanical variety zschackei is a catch-all group that encompasses populations distributed throughout temperate North America 
and possibly southward into the northern Andes (Wilson, 1981; Wilson and Heiser, 1979). A third subspecies, jonesianum, was created to encompass extinct cultigens from eastern North America (Smith and Yarnell, 2009). Botanical varieties of C. berlandieri are differentiated mostly by subtle morphological characters such as seed size, the presence of bracteate leaves, and pericarp coloration, along with habitat preference.

In this report, we outline recent pitseed goosefoot collection efforts in North America; recent observations regarding hybridization between quinoa and pitseed goosefoot and selection of individuals with desirable production characteristics from selfed progeny of these crosses; and sequencing efforts designed to narrow the list of potential A-genome ancestors of the C. berlandieri/hircinum/quinoa allotetraploid species complex. The principal objectives of the collection efforts in 2018 were as follows: 1) to determine if unique spring-fruiting $C$. berlandieri var. berlandieri is present in the mildwinter environment of subtropical southern Texas and to conduct the first systematic seed collection for this ecotype; 2) to expand the very limited existing collections and determine the degree of morphological variation present in New England coastal var. macrocalycium; 3 ) to determine the presence and variety of likely heat-tolerant strains of $C$. berlandieri within the southern Great Plains; and 4) to identify Chenopodium diploids (putatively, with an A-genome) sympatric with pitseed goosefoot in these regions.

\section{Materials And Methods}

\section{Pitseed goosefoot seed collection expeditions} in 2018

Personnel from Brigham Young University (BYU) made seed collection trips in 2018 to southern Texas (April), the New England coast (September), and Oklahoma (October). Seeds were sampled from populations encountered on publicly accessible roadside rights-of-way and public beaches, generally guided by previous collection sites noted on herbarium specimens. Maps of the three collections are included in Fig. 1. Collection site passport data and putative identification of $C$. berlandieri and accessions of other selected species were noted and are presented in Table 1.

Fruits from Chenopodium population samples were photographed at BYU using a BK PLUS Lab System (Dun Inc., Palmyra, Virginia, USA) with a $65-\mathrm{mm}$ Canon (Melville, New York, USA) Macro lens at f4-5.6 with 1.5x-4x magnification. Images were captured using Capture One Pro 64 bit v. 10.2.1 (Phase One, New York, USA) and superimposed using Stacker v. 1.04 (Zerene Systems, Richland, Washington, USA), with contrast adjustment and sharpening performed using the Smart Sharpen tool in Photoshop x64 v. 12.0 (Adobe Inc., San Jose, California, USA).
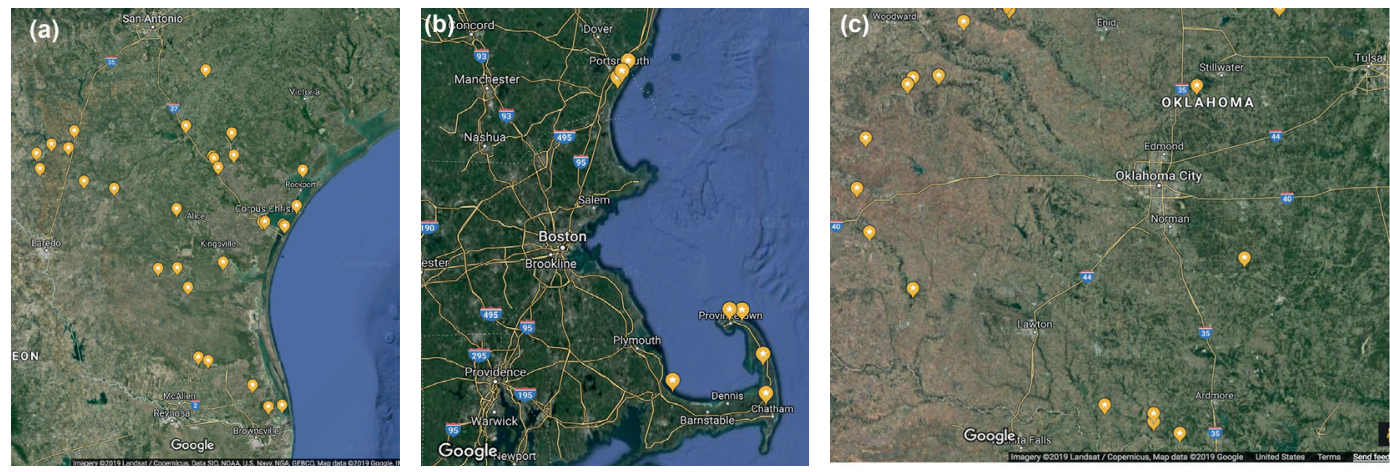

Figure 1. Maps of BYU Chenopodium collection trips in 2018. (a) Southern Texas; (b) New England; (c) Oklahoma. 
Table 1. Chenopodium collections by BYU personnel in 2018. Chenopodium berlandieri taxa: BERB=var. berlandieri; $\mathrm{BERC}=$ var. boscianum; $\mathrm{BERL}=$ unclassified variety; $\mathrm{BERM}=\mathrm{var}$. macrocalycium; $\mathrm{BERS}=\mathrm{var}$. sinuatum; and $\mathrm{BERZ=var}$. zschackei. $\mathrm{ALBE}=$ C. albescens; $\mathrm{UND}=$ undetermined species.

\begin{tabular}{|c|c|c|c|c|c|c|c|}
\hline No. & Taxa & Date & County & State & Latitude & Longitude & Elevation \\
\hline 1801 & BERB & $4-19$ & La Salle & Texas & 28.4284 & -99.2514 & 118 \\
\hline 1802 & BERB & $4-19$ & Cotulla & Texas & 28.2828 & -99.3045 & 147 \\
\hline 1803 & ALBE & $4-19$ & Dimmit & Texas & 28.3135 & -99.4723 & 159 \\
\hline 1804 & BERB & $4-19$ & Dimmit & Texas & 28.2342 & -99.6142 & 176 \\
\hline 1805 & BERB & $4-19$ & Webb & Texas & 28.1037 & -99.5791 & 201 \\
\hline 1806 & BERB & $4-19$ & Webb & Texas & 27.9998 & -99.1494 & 117 \\
\hline 1807 & BERB & $4-19$ & Webb & Texas & 27.9407 & -98.8594 & 120 \\
\hline 1808 & ALBE & $4-19$ & Webb & Texas & 27.9407 & -98.8594 & 120 \\
\hline 1809 & ALBE, BERB & $4-19$ & Duval & Texas & 27.5821 & -98.4355 & \\
\hline 1810 & ALBE & $4-20$ & Duval & Texas & 27.5821 & -98.4355 & 126 \\
\hline 1811 & ALBE & $4-20$ & Jim Hogg & Texas & 27.2954 & -98.6317 & 154 \\
\hline 1812 & BERB & $4-20$ & Brooks & Texas & 27.2568 & -98.4297 & 79 \\
\hline 1813 & ALBE & $4-20$ & Brooks & Texas & 27.2568 & -98.4297 & 79 \\
\hline 1814 & BERB & $4-20$ & Brooks & Texas & 27.2625 & -98.2495 & 58 \\
\hline 1815 & ALBE & $4-20$ & Brooks & Texas & 27.2625 & -98.2495 & 58 \\
\hline 1816 & ALBE, UND & $4-20$ & Brooks & Texas & 27.1569 & -98.0714 & 19 \\
\hline 1817 & BERB & $4-20$ & Brooks & Texas & 27.0962 & -98.1463 & 32 \\
\hline 1818 & BERB & $4-20$ & Hidalgo & Texas & 26.4989 & -98.0451 & 22 \\
\hline 1819 & BERB & $4-20$ & Willacy & Texas & 26.4686 & -97.9517 & 16 \\
\hline 1820 & BERB & $4-20$ & Cameron & Texas & 26.0711 & -97.3765 & 3 \\
\hline 1821 & BERC & $4-20$ & Cameron & Texas & 26.0803 & -97.2489 & 3 \\
\hline 1822 & BERB & $4-20$ & Cameron & Texas & 26.2553 & -97.5286 & 15 \\
\hline 1823 & BERB & $4-21$ & Kleberg & Texas & 27.3099 & -97.8101 & 4 \\
\hline 1824 & BERB & $4-21$ & Nueces & Texas & 27.6545 & -97.4298 & 6 \\
\hline 1825 & BERC & $4-21$ & Nueces & Texas & 27.6565 & -97.4023 & 10 \\
\hline 1826 & BERC & $4-21$ & Nueces & Texas & 27.63 & -97.2295 & 0 \\
\hline 1827 & BERC & $4-21$ & Nueces & Texas & 27.6194 & -97.2119 & 0 \\
\hline 1828 & BERC & $4-21$ & Nueces & Texas & 27.7903 & -97.0958 & 6 \\
\hline 1829 & BERC & $4-21$ & Aransas & Texas & 28.0951 & -97.0322 & 0 \\
\hline 1830 & BERB & $4-21$ & Bee & Texas & 28.4169 & -97.7219 & 60 \\
\hline 1831 & BERB & $4-21$ & Bee & Texas & 28.2265 & -97.7027 & 49 \\
\hline 1832 & BERB & $4-21$ & Live Oak & Texas & 28.1984 & -97.8939 & 42 \\
\hline 1833 & BERB & $4-21$ & Live Oak & Texas & 28.2176 & -97.9066 & 41 \\
\hline 1834 & BERB & $4-21$ & Live Oak & Texas & 28.4776 & -98.1658 & 60 \\
\hline 1835 & BERB & $4-21$ & Karnes & Texas & 28.9567 & -97.9739 & 86 \\
\hline 1836 & BERB & $4-21$ & San Patricio & Texas & 28.1229 & -97.8521 & 40 \\
\hline 1856 & BERM & $9-21$ & Barnstable & Massachusetts & 41.7663 & -70.4816 & 0 \\
\hline 1857 & BERM & $9-21$ & Barnstable & Massachusetts & 41.8717 & -70.0088 & 0 \\
\hline 1858 & BERM & $9-21$ & Barnstable & Massachusetts & 42.0496 & -70.1183 & 0 \\
\hline 1859 & BERM & $9-21$ & Barnstable & Massachusetts & 42.0514 & -70.1849 & 2 \\
\hline 1860 & BERM & $9-21$ & Barnstable & Massachusetts & 41.7121 & -69.9933 & 1 \\
\hline 1861 & BERM & $9-21$ & Barnstable & Massachusetts & 41.7121 & -69.9933 & 2 \\
\hline 1862 & BERM & $9-22$ & Rockingham & New Hampshire & 43.0417 & -70.7153 & 2 \\
\hline 1863 & BERM & $9-22$ & Rockingham & New Hampshire & 43.0025 & -70.7478 & 2 \\
\hline 1864 & BERM & $9-22$ & York & Maine & 43.3439 & -70.4987 & 1 \\
\hline 1878 & BERS & $10-03$ & Payne & Oklahoma & 35.9766 & -97.2384 & 276 \\
\hline 1879 & BERS & $10-03$ & Osage & Oklahoma & 36.435 & -96.6313 & 262 \\
\hline 1880 & BERS & $10-03$ & Osage & Oklahoma & 36.4781 & -96.949 & 284 \\
\hline 1883 & BERZ & $10-03$ & Alfalfa & Oklahoma & 36.7823 & -98.1695 & 356 \\
\hline 1886 & BERL & $10-03$ & Alfalfa & Oklahoma & 36.7632 & -98.1282 & 379 \\
\hline 1887 & BERL & $10-03$ & Alfalfa & Oklahoma & 36.6664 & -98.1984 & 373 \\
\hline 1891 & BERL & $10-04$ & Woods & Oklahoma & 36.4361 & -98.5873 & 444 \\
\hline 1893 & BERL & $10-04$ & Woods & Oklahoma & 36.4833 & -98.6757 & 444 \\
\hline 1894 & BERL & $10-04$ & Woods & Oklahoma & 36.5212 & -98.7466 & 473 \\
\hline 1896 & BERL & $10-04$ & Major & Oklahoma & 36.3621 & -98.8958 & 535 \\
\hline 1897 & BERL & $10-04$ & Dewey & Oklahoma & 36.0434 & -99.0741 & 553 \\
\hline 1899 & BERZ & $10-04$ & Dewey & Oklahoma & 36.0298 & -99.257 & 628 \\
\hline 18101 & BERZ & $10-04$ & Roger Mills & Oklahoma & 35.6715 & -99.5876 & 575 \\
\hline 18102 & BERZ & $10-04$ & Beckham & Oklahoma & 35.3742 & -99.6467 & 584 \\
\hline 18103 & BERZ & $10-04$ & Greer & Oklahoma & 35.115 & -99.554 & 512 \\
\hline 18105 & BERS & $10-05$ & Jefferson & Oklahoma & 34.0856 & -97.9115 & 282 \\
\hline 18106 & BERS & $10-05$ & Jefferson & Oklahoma & 33.9843 & -97.5701 & 257 \\
\hline 18107 & BERS & $10-05$ & Jefferson & Oklahoma & 34.0335 & -97.5698 & 240 \\
\hline 18109 & BERS & $10-05$ & Love & Oklahoma & 33.9112 & -97.3902 & 286 \\
\hline 18110 & BERS & $10-05$ & Pottawatomie & Oklahoma & 34.9493 & -96.9221 & 291 \\
\hline
\end{tabular}


DNA sequence analysis of C. pallidicaule, C. watsonii, and $\mathrm{C}$. sonorense

Raw DNA sequence reads for $C$. pallidicaule USDA accession PI 478407 (BYU 1652; Jarvis et al., 2017), C. watsonii accession BYU 873 (Yavapai Co., Arizona), and C. sonorense Benet-Pierce \& M.G. Simpson accession BYU 17220 (Santa Cruz Co., Arizona) were generated by the Novogene Corporation (Chula Vista, California, USA) using an Illumina (San Diego, California, USA) highfidelity, short-read platform. Raw reads were then trimmed using Trimmomatic (Bolger et al., 2014), removing low-quality reads and Illumina adapters. Reads from each accession were aligned to the quinoa QQ74 published reference genome (Jarvis et al., 2017) using BWA-MEM ( $\mathrm{Li}, 2013)$, and SAM files were then converted to BAM format, sorted and indexed using SAMtools v1.9 (Li et al., 2009). The GATK CollectAlignmentSummaryMetrics subprogram was used to generate mapping statistics (McKenna et al., 2010).

\section{Results}

Collection trips to Texas, New England, and Oklahoma in 2018

The trip to southern Texas in April resulted in the collection of seeds from 23 populations of
C. berlandieri var. berlandieri; eight sympatric populations of putative diploid, broad-leaved $C$. albescens, which at one location (BYU 1816) was intermixed with a third narrow-leaved species that might have been $C$. pratericola; and six populations of the Gulf Coastal ecotype C. berlandieri var. boscianum (Table 1, Fig. 1a). The var. berlandieri populations all emitted a fetid trimethylamine odor and were mostly found on highly disturbed roadsides, including areas where seasonally dry riverbeds intersected the highway. The var. boscianum populations also smelled strongly of trimethylamine, were restricted to sandy barrier islands and tidal estuary margins, tended towards later maturity, and were more glabrous than var. berlandieri. Both ecotypes included populations of plants having semi-compact to compact inflorescences, with and without extensive stem branching. As shown in Fig. 2, var. boscianum included populations with significantly larger fruits, which approached $1.8 \mathrm{~mm}$ in diameter.

The collection trip to the New England coast in September yielded seeds from nine populations of $C$. berlandieri var. macrocalycium (Table 1 and Figs. $1 \mathrm{~b}$ and 3 ). This was a fairly common species in disturbed beach sand, especially among decaying seaweed at the high-tide line. Plants displayed a consistent phenotype with excessive branching, a yellow-green and glabrous appearance, and fruits to $2 \mathrm{~mm}$ in diameter in
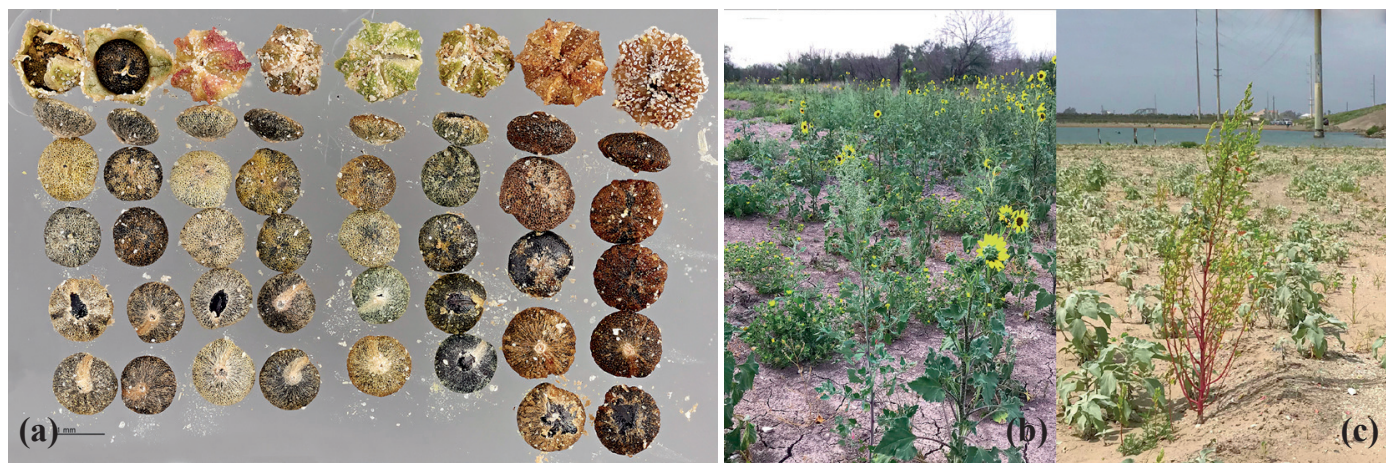

Figure 2. (a) Comparison of fruits of $C$. berlandieri vars. berlandieri and boscianum from southern Texas. In the columns, from left to right: var. berlandieri populations BYU 1814, BYU 1818, BYU 1822, and BYU 1833; var. boscianum populations BYU 1821, BYU 1825, BYU 1828, and BYU 1829. (b) Typical habitat of C. berlandieri var. berlandieri (BYU 1806) on cracked alkaline clay with Helianthus spp. (c) Typical habitat of C. berlandieri var. boscianum (BYU 1827) in sandy substrate on Mustang Island. 
small, widely spaced glomerules and fairly uniform in maturity. At the Chatham Estuary of Cape Cod, populations extended a few meters into adjacent deciduous forest, where they were noticeably shorter in the shade. Notably, at least one population on the New Hampshire coast was being attacked by a stem-weakening, boring maggot (Fig. 3c).

The collection trip to Oklahoma in October (Table 1 and Fig. 1c) resulted in eight collections of $C$. berlandieri var. sinuatum, four of var. zschackei, and eight of a hitherto unidentified variety with characteristics similar to those of vars. zschackei (yellow area at the stylar base) and berlandieri (strong trimethylamine odor and more conical fruit side profile). Figure 4 compares fruits from three populations of each of these ecotypes. Variety sinuatum was more common in northeastern Oklahoma, with var. zschackei predominant in the southeast and the unnamed variety more common in the western part of the state. At all sites, the species was strongly associated with disturbed, sandy soils and was especially common along roadsides that intersected with arroyos and seasonally flooded riverbanks.

In addition to the $C$. berlandieri accessions, we collected seeds from 12 populations of unidentified narrow-leaved species bearing utriculate fruits. We are currently working to identify these putative diploids via fruit morphology and DNA analyses.
Recovery of significant breeding traits from $C$. berlandieri x C. quinoa hybrids

We herein provide some examples that demonstrate the value of ecologically variable pitseed goosefoot as a quinoa improvement resource. These examples are from intertaxa populations derived via either spontaneous field crosses or intentional greenhouse crosses (Fig. 5).

Figure 5a shows vigorous and relatively uniform $\mathrm{F}_{2: 5}$ plants (O108-1-11-17-1 parent) derived from a cross between 'Ollague' and BYU 14108, a var. sinuatum accession collected in October 2014 in a torrid oak-grassland steppe in Cochise Co., Arizona. A single black-seeded hybrid plant was identified in the greenhouse after growing seeds harvested from a heat-stressed 'Ollague' plant exposed to BYU 14108 pollen. Among the 178 $\mathrm{F}_{2}$ plants showing widely variable morphology in terms of plant architecture, seed size, and seed coloration, 169 (94.9\%) produced at least one seed, and all but a few produced many more than five seeds. Only two of the plants, however, produced seeds that were not black, one of which (O108-1-11) bore white seeds that were similar in size to those of 'Ollague'.

Figure $5 \mathrm{~b}$ shows representative fruit size and color variation in the parent, $\mathrm{F}_{1}$, and $\mathrm{F}_{2}$ plants (population R1R-2) derived from a cross between quinoa cv. 'Real-1' and BYU 937, a var. boscianum accession

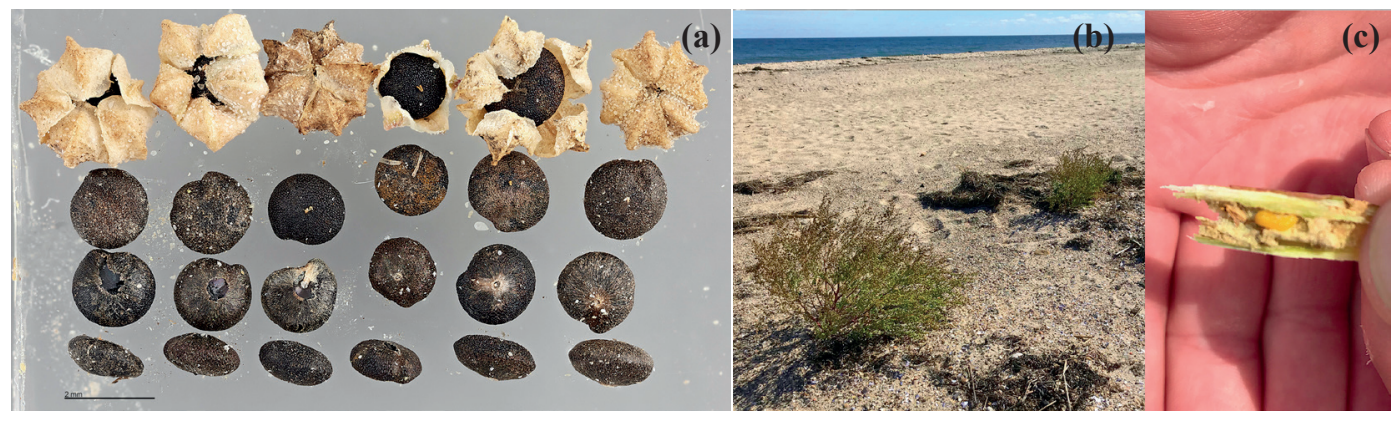

Figure 3. (a) Fruits of six C. berlandieri var. macrocalycium populations from New England. In the columns, from left to right: BYU 1856, BYU 1857, BYU 1859, BYU 1860, BYU 1863, and BYU 1864. (b) Var. macrocalycium growing typically along the high-tide line among seaweed detritus at Sandwich Beach, Cape Cod, Massachusetts (BYU 1856). (c) Unidentified stem-boring maggot infecting var. macrocalycium plants at Odiorne Point State Park, New Hampshire. 

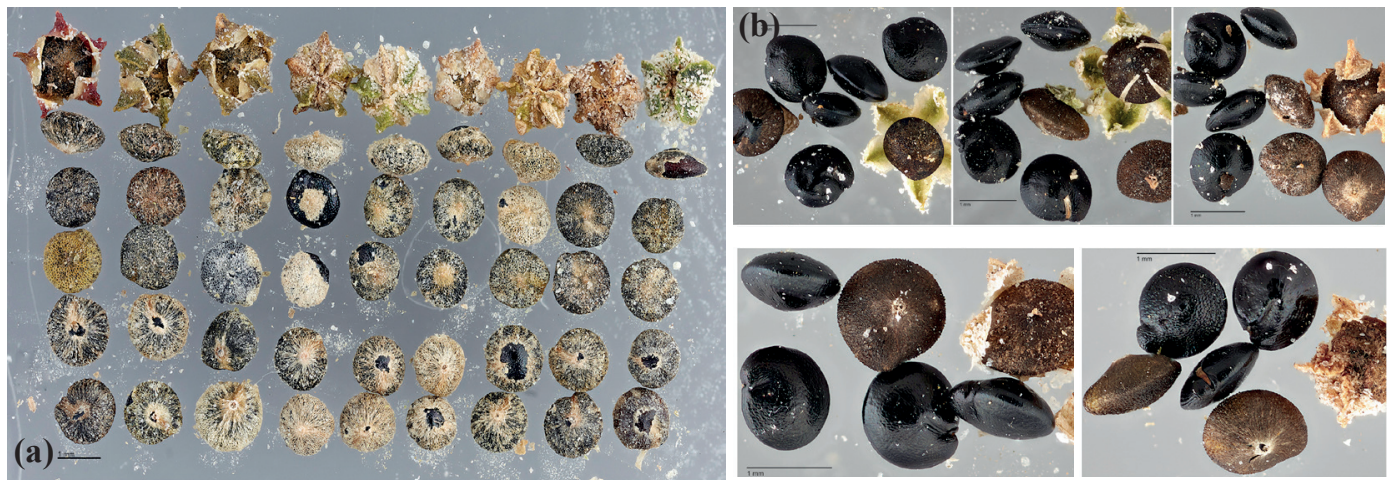

Figure 4. (a) Comparison of fruits of $C$. berlandieri from Oklahoma. In the columns, from left to right: var. sinuatum collections BYU 1878, BYU 1879, and BYU 1880; var. unknown collections BYU 1883, BYU 1886, and BYU 1887; and var. zschackei collections BYU 1899, BYU 18101, and BYU 18102. (b) Fruits of Chenopodium subsect. Leiosperma diploids collected in Oklahoma. Clockwise from middle left: BYU 1881 (Alfalfa Co.); BYU 1888 (Woods Co.); BYU 1892 (Woods Co.); BYU 18100 (Dewey Co.); and BYU 18108 (Love Co.).
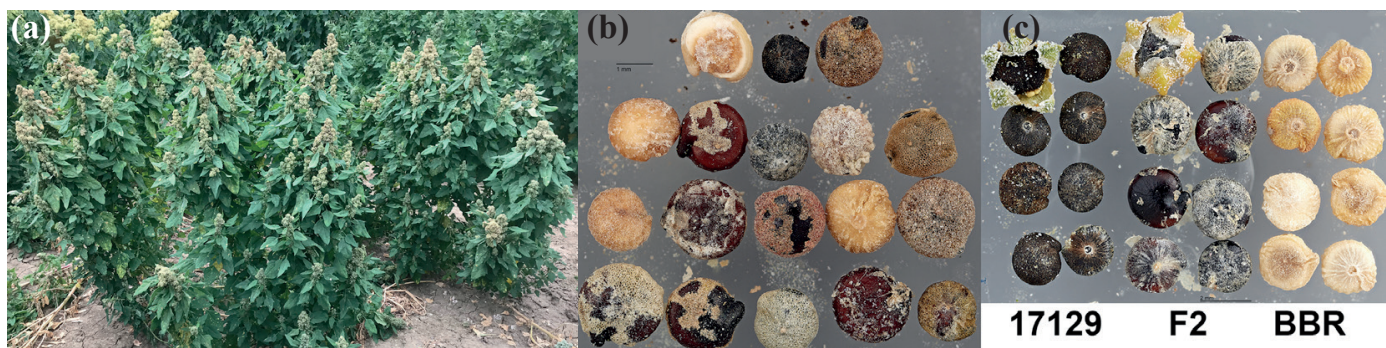

Figure 5. Characteristics of plants derived from hybridization between C. berlandieri and C. quinoa. (a) Plot of selected $\mathrm{F}_{2.5}$ plants (O108-1-11-17-1 parent) derived from a cross between Salares quinoa cv. 'Ollague' and BYU 14108 growing at the University of California Hansen Agricultural Experiment Station near Los Angeles, California, in June 2018. BYU 14108 (var. sinuatum) was collected in October 2014 in the torrid upper Sonoran oak-grassland savanna zone near the Chiricahua Mountains in southern Arizona. (b) Variation in fruit size and color in the 'Real-1' (top row, left) and BYU 937 (top row, middle) parents, $F_{1}$ plants (top row, right) and fifteen $\mathrm{F}_{2}$ plants of population R1R-2. BYU 937 (var. boscianum) was a single plant collected along the shore of the Galveston Bay estuary, Texas, in August 2009. (c) Fruits from one earlymaturing $\mathrm{F}_{2}$ derived from a quinoa cv. 'Brightest Brilliant Rainbow' $\mathrm{x}$ var. macrocalycium hybrid showing transgressive segregation for large seed size. The $\mathrm{F}_{1}$ parent was identified in a row of Brightest Brilliant Rainbow growing at the Woodman Research Farm at the University of New Hampshire Agricultural Experiment Station in September 2018, and seeds from that plant were kindly provided by UNH Professor Tom Davis; $17129=$ var. macrocalycium parent; BBR $=$ Brightest Brilliant Rainbow.

collected in August 2009 at the high-tide line along the sandy shore of Galveston Bay, Texas. Multiple black-seeded, foul-smelling hybrids were recovered from seeds taken off a heat-stressed Real-1 plant that had been exposed to BYU 937 pollen in the greenhouse, one of which produced population R1R-2. The hybrid bore seeds that were similar in size to those of 'Real-1', while several $\mathrm{F}_{2}$ plants produced seeds that exceeded the size of those of the quinoa parent, despite the fact that the var. boscianum parent produces seeds that are only slightly larger than $1 \mathrm{~mm}$ in diameter (Fig. 5b). This transgressive segregation pattern suggests that BYU 937 harbors at least one complementary allele for large seed size.

During the New England collection trip in September 2018, inspection of a row of 'Brightest Brilliant Rainbow' quinoa at the University of New Hampshire Experimental Farm in Durham revealed the presence of a putative $F_{1}$ plant that was very large and bushy with some phenotypic characteristics reminiscent of var. macrocalycium. Approximately 60 large, black seeds from this plant were kindly provided by Tom Davis and subsequently planted in the greenhouse at BYU, 
resulting in plants with a wide array of wholeplant and panicle morphologies, from compact to exceptionally lax. Figure 5c presents seeds from one early-maturing, putative $\mathrm{F}_{2}$ showing transgressive segregation for large seed size. We previously noted in an 'Ingapirca' $\mathrm{x}$ var. macrocalycium cross that segregants in the $\mathrm{F}_{2}$ and subsequent generations were universally heat susceptible, produced less than $50 \%$ fertile progeny, and produced no individuals with large seeds that did not also have highly lax panicles (personal observations).

Comparison of genomic DNA sequences of $\mathrm{C}$. watsonii, C. sonorense, and C. pallidicaule with the quinoa $Q Q 74$ reference genome

Table 2 presents a summary of trimmed short-read sequence mapping of three A-genome diploids wild Watson's stinking goosefoot, wild Sonoran goosefoot and cultivated cañahua - to the lowland QQ74 quinoa reference genome reported in Jarvis et al. (2017). Although all three species are closely related to quinoa and belong to the A-genome diploid group, sequencing reads of Watson's stinking goosefoot showed the highest mapping percentage and the lowest mismatch rate, whereas cañahua showed the lowest mapping percentage and the highest mismatch rate.

\section{Discussion}

The diverse seed collections described herein represent a very valuable resource for improving cultivated quinoa's resistance to pests and diseases. Taking an alternative perspective, the relatively limited pool of highly diverse quinoa strains legally available to breeders outside the Andean region can be viewed as a source of domestication traits for redomesticating pitseed goosefoot. This is a potential staple food crop that is already biologically adapted to diverse warm-season temperate and subtropical production environments. Analyses of seed components have revealed that pitseed goosefoot and its hybrid derivatives have nutritional value comparable to that of quinoa (unpublished). This result is consistent with pitseed goosefoot, known as kipahki in the Skiri Pawnee language, having been a foundational food source in indigenous eastern North American agriculture five centuries prior to the sixteenth-century arrival of Europeans.

Mounting evidence from DNA sequencing and cytogenetic studies indicates that $C$. watsonii or a very close relative that is unrecognized, unanalyzed, or extinct is the donor of the A genome's chromosome sets and cytoplasmic DNA found in pitseed goosefoot and quinoa (Jarvis et al., 2017; Kolano et al., 2016; Walsh et al., 2015; Storchova

Table 2. Summary metrics of trimmed (40-Gb pretrimmed) Illumina short-sequence paired reads of genomic DNA from the A-genome diploids C. watsonii, C. sonorense, and C. pallidicaule mapped to the C. quinoa accession QQ74 wholegenome reference (Jarvis et al., 2017).

\begin{tabular}{|c|c|c|c|c|c|}
\hline & $\begin{array}{l}\text { Reads Aligned } \\
(\%)\end{array}$ & $\begin{array}{c}\text { Mismatch Rate } \\
(\%)\end{array}$ & $\begin{array}{l}\text { High-Quality Error Rate } \\
(\%)\end{array}$ & $\begin{array}{c}\text { Indel Rate } \\
(\%)\end{array}$ & $\begin{array}{l}\text { Reads Aligned in } \\
\text { Pairs }(\%)\end{array}$ \\
\hline \multicolumn{6}{|l|}{ C. watsonii } \\
\hline First of pair & 98.37 & 3.18 & 3.02 & 0.28 & 99.30 \\
\hline Second of pair & 98.36 & 3.20 & 3.04 & 0.27 & 99.32 \\
\hline Pair & 98.36 & 3.19 & 3.03 & 0.28 & 99.31 \\
\hline \multicolumn{6}{|l|}{ C. sonorense } \\
\hline First of pair & 98.36 & 3.39 & 3.24 & 0.28 & 99.21 \\
\hline Second of pair & 98.33 & 3.43 & 3.27 & 0.28 & 99.24 \\
\hline Pair & 98.34 & 3.41 & 3.26 & 0.28 & 99.23 \\
\hline \multicolumn{6}{|l|}{ C. pallidicaule } \\
\hline First of pair & 95.36 & 3.45 & 3.54 & 0.27 & 98.52 \\
\hline Second of pair & 95.34 & 3.46 & 3.55 & 0.27 & 98.54 \\
\hline Pair & 95.35 & 3.46 & 3.55 & 0.27 & 98.53 \\
\hline
\end{tabular}


et al., 2015). These same studies have pointed to Eurasian C. ficifolium and C. suecicum as the Bgenome donors. Ongoing work will involve longread DNA sequencing and chromatin proximity mapping to assemble these diploid genomes into pseudochromosome-scale assemblies. Additional efforts will focus on the collection and sequencing of other North American Chenopodium diploids and, in conjunction with Latin American colleagues, the collection and sequencing of South American species. Although Andean cañahua ( $C$. pallidicaule) does not appear to be the direct ances- tor of C. quinoa, the scientific community should accelerate efforts to study, improve, conserve, and utilize this unique high-altitude food crop.

\section{Acknowledgments}

The authors express gratitude to Tom Davis (UNH) for sharing seeds of the Brightest Brilliant Rainbow $\mathrm{x}$ C. berlandieri var. macrocalycium $\mathrm{F}_{1}$ plant and to Tom Davis, David Brenner and BYU student Zach Jaramillo for helping with seed collections.

\section{Resumen}

E.N. Jellen, D.E. Jarvis, S.P. Hunt, H.H. Mangelsen, y P.J. Maughan. 2019. Nuevas colecciones de semillas de pata de gallo norteamericano (Chenopodium berlandieri) y esfuerzos para identificar a sus antepasados diploides a través de la secuenciación de todo el genoma. Cien. Inv. Agr. 46(2): 187-196. Pata de gallo (Chenopodium berlandieri) es una especie norteamericana, silvestre y muy diversa en su ecología, tal que representa un recurso genético para mejorar la quinua sudamericana (Chenopodium quinoa). Ambas entidades taxonómicas son alotetraploides con 36 cromosomas compuestas en subgenomas AA y BB. El genoma A se encuentra en muchos diploides de las Américas, junto con una especie del noreste de Asia, y recientemente fue identificado como pariente maternal, mientras el genoma paternal B se relaciona a un grupo de diploides de Eurasia. Dos de nuestros objetivos principales eran 1) determinar la diversidad genética que hay en el complejo alotetraploide de C. berlandieri-quinoa-hircinum; y 2) caracterizar el sendero evolucionario de poliploidización hasta domesticación en este grupo taxonómico. Para investigar la diversidad genética, en el año 2018 hicimos colecciones de semillas de poblaciones de $C$. berlandieri y diploides simpátricos en el sur de Texas, el sur de los Llanos Grandes, y en el litoral de Nueva Inglaterra. Referente al segundo objetivo, secuenciamos los genomas de dos diploides AA de la subsección Cellulata del Desierto de Sonora y el cultivar andino cañahua C. pallidicaule de subsección Leiosperma. Al alinear leídas pareadas de estos diploides con la secuencia referencia de C. quinoa cultivar 'QQ74', los porcentajes que coincidieron eran 99.31, 99.23, and 98.53 para C. watsonii, C. sonorense, y C. pallidicaule, respectivamente. Estos datos aportan la hipótesis que, de entre estas tres $C$. watsonii es la especie más cercana al ancestro AA de la quinua. Continuamos nuestros esfuerzos en secuenciar un panel más amplio de diploides con el fin de identificar con más seguridad el ancestro maternal de C. quinoa y C. berlandieri, sea que todavía existe.

Palabras clave: Chenopodium, quinua, recursos genéticos, secuenciación de ADN.

\section{References}

Benet-Pierce, N., and M.G. Simpson. 2017. Taxonomic recovery of the species in the Chenopodium neomexicanum (Chenopodiaceae) complex and description of Chenopodium sonorense sp. nov. Journal of the Torrey Botanical Society 144(3):339-356.

Bolger, A.M., M. Lohse, and B. Usadel. 2014. Trimmomatic: a flexible trimmer for Illumina sequence data. Bioinformatics 30:21142120 . 
Brown, D.C., V. Cepeda-Cornejo, P.J. Maughan, and E.N. Jellen. 2015. Characterization of the granulebound starch synthase I gene in Chenopodium. The Plant Genome 8(1):1-12.

Gremillion, K.J. 1993. Crop and weed in prehistoric eastern North America: the Chenopodium example. American Antiquity 58(3):496-509.

Hodkova, E., and B. Mandak. 2018. An overlooked hybrid between the two diploid Chenopodium species in Central Europe determined by microsatellite and morphological analysis. Plant Systematics and Evolution 304:295-312.

Jarvis, D.E., Y.S. Ho, D.J. Lightfoot, S.M. Schmockel, B. Li, T.J.A. Borm, H. Ohyanagi, K. Mineta, C.T. Michell, N. Saber, N.M. Kharbatia, R.R. Rupper, A.R. Sharp, N. Dally, B.A. Boughton, Y.H. Woo, G. Gao, E.G.W.M. Schijlen, X. Guo, A.A. Momin, S. Negrao, S. Al-Babili, C. Gehring, U. Roessner, C. Jung, K. Murphy, S.T. Arold, T. Gojobori, C.G. van der Linden, E.N. van Loo, E.N. Jellen, P.J. Maughan, and M. Tester. 2017. The genome of Chenopodium quinoa. Nature 542:307-312.

Kistler, L., and B. Shapiro. 2011. Ancient DNA confirms a local origin of domesticated chenopod in eastern North America. Journal of Archaeological Science 38:3549-3554.

Kolano, B., J. McCann, M. Orzechowska, D. Siwinska, E. Temsch, and H. Weiss-Schneeweiss. 2016. Molecular and cytogenetic evidence for an allotetraploid origin of Chenopodium quinoa and C. berlandieri (Amaranthaceae). Molecular Phylogenetics and Evolution 100:109-123.

Li, H. 2013. Aligning sequence reads, clone sequences and assembly contigs with BWA-MEM. ArXiv: 1303.

Li, H., B. Handsaker, A. Wysoker, T. Fennell, J. Ruan, N. Homer, G. Marth, G. Abecasis, R. Durbin, and 1000 Genome Project Data Processing Subgroup. 2009. The Sequence Alignment/Map format and SAMtools. Bioinformatics 25:2078-2079.
Maughan, P.J., L. Chaney, D.J. Lightfoot, B.J. Cox, M. Tester, E.N. Jellen, and D.E. Jarvis. 2019. Mitochondrial and chloroplast genomes provide insights into the evolutionary origins of quinoa (Chenopodium quinoa Willd.). Scientific Reports 9:185.

McKenna A., M. Hanna, E. Banks, A. Sivachenko, K. Cibulskis, A. Kernytsky, K. Garimella, D. Altshuler, S. Gabriel, M. Daly, and M.A. DePristo. 2010. The Genome Analysis Toolkit: a MapReduce framework for analyzing next-generation DNA sequencing data. Genome Research 20:1297-1303.

Smith, B.D. 1984. Chenopodium as a prehistoric domesticate in eastern North America: evidence from Russell Cave, Alabama. Science 226:165-167.

Smith, B.D., and R.A. Yarnell. 2009. Initial formation of an indigenous crop complex in eastern North America at 3800 B.P. Proceedings of the National Academy of Sciences USA 106(16):6561-6566.

Storchova, H., J. Drabesova, D. Chab, J. Kolar, and E.N. Jellen. 2015. The introns in Flowering Locus T-Like $(F T L)$ genes are useful markers for tracking paternity in tetraploid Chenopodium quinoa Willd. Genetic Resources and Crop Evolution 62(6):913-925.

Walsh, B.M., D. Adhikary, P.J. Maughan, E. Emshwiller, and E.N. Jellen. 2015. Chenopodium polyploidy inferences from Salt Overly Sensitive 1 ( $S O S 1)$ data. American Journal of Botany 102(4):533-543.

Wilson, H.D. 1981. Genetic variation among South American populations of tetraploid Chenopodium sect. Chenopodium subsect. Cellulata. Systematic Botany 6(4):380-398.

Wilson, H.D., and C.B. Heiser, Jr. 1979. The origin and evolutionary relationships of 'Huauzontle' (Chenopodium nuttaliae Safford), domesticated chenopod of Mexico. American Journal of Botany 66(2):198-206.

Wilson, H., and J. Manhart. 1993. Crop/weed gene flow: Chenopodium quinoa Willd. and C. berlandieri Moq. Theoretical and Applied Genetics 86:642-648. 